\title{
Measurement of Background Ionizing Radiation Exposure Levels in Selected Farms in Communities of Ishielu LGA, Ebonyi State, Nigeria
}

\author{
UGBEDE, F O \\ Departmentt of Physics with Electronics, Evangel University Akaeze, Ebonyi State, Nigeria. \\ Corresponding Author Email: oghene4fred@yahoo.com; ugbedefred@evangeluniversity.edu.ng
}

\begin{abstract}
The perceived implication of increase background radiation levels of farm lands due to inputs of fertilizers and agrochemicals has suggested the need to investigate the background ionization radiation (BIR) levels and associated radiation health parameters in farmlands located in communities of Ishielu LGA of Ebonyi State, Nigeria. An in-situ method of BIR measurement in five farmlands each located in Nkalagu, Ezillo, Okpoto and Nteze communities was carried out using portable GQ GMC-320 Plus radiation meter at an elevation of $1.0 \mathrm{~m}$ above ground level with a GPS for geographical location. The BIR levels observed in Nkalagu and Ezillo farmlands are high ranging with same mean values of $0.016 \pm 0.002 \mathrm{mR} / \mathrm{h}$ which is higher than $0.013 \mathrm{mR} / \mathrm{h}$ ICRP recommendations for normal environment. The BIR measured at Okpoto and Nteze farmlands are low ranging with mean values of $0.013 \pm 0.001 \mathrm{mR} / \mathrm{h}$ which is in tandem with ICRP recommendation. The corresponding absorbed doses in all the farmlands and associated excess lifetime cancer risks are far higher than their recommended safe limit of $84.0 \eta \mathrm{Gy} / \mathrm{h}$ and $0.29 \times 10^{-3}$ respectively. The values for the annual effective dose for all the farm lands are lower than the permissible limits of $1.00 \mathrm{mSv} / \mathrm{yr}$ for the general public. The study shows that the radiation levels and the doses observed in the farmlands do not constitute any immediate negative radiological health effect on the farmers and general public. However, there exists the possibility of cancer development due to accumulated doses as suggested by the excess lifetime cancer risk values.
\end{abstract}

\section{DOI: https://dx.doi.org/10.4314/jasem.v22i9.11}

Copyright: Copyright $\odot 2018$ Ugbede. This is an open access article distributed under the Creative Commons Attribution License (CCL), which permits unrestricted use, distribution, and reproduction in any medium, provided the original work is properly cited.

Dates: Received: 08 August2018; Revised: 21 September 2018; Accepted: 29September 2018

Keywords: Background radiation levels, absorbed doses, farm lands, Ishielu communities

Background radiation is part of the natural environment and as such humans and other living organisms are continuously exposed. Background ionizing radiation was originally attributed to natural sources. This has over the years increased due to human activities and has been of great concern because of the known effects of exposure to higher doses (Ononugbo and Mgbemere, 2016). The main natural sources of radiation includes cosmic rays that enter the earth from outer space and the naturally occurring radioactive elements of the uranium and thorium series and non-series radioactive potassium (Farai and Jibiri, 2000; Benson and Ugbede, 2018) which are characterized with half-lives comparable to the age of the earth (Sharma et al., 2017) and are present everywhere in the environment; in rocks, soil, water, sediments, foods and including the human body itself (UNSCEAR, 2008). The concentration and gamma radiation from the radioactive nuclides vary significantly, depending on the geological and geographical features of the region (Sharma et al., 2017). The use of radiation sources in medical diagnosis and therapy, nuclear weapons, nuclear power plants, fertilizers production, research institutions as well as in consumers' products have contributed to increase in background radiation exposure and doses.

Owing to the recent drive of the federal government of Nigeria to diversify the economy through agriculture, farming has been recognized as a major alternative of income generation and many individuals especially in the rural settings have engaged themselves in such act. Farming which is a major part of agriculture involves activities which alter the natural characteristics of the top soil. Activities such as applications of high yielding fertilizers inputs and chemicals for controlling weeds and pests can greatly enhance natural radioactivity and radiation levels of farm soil and the farm environment as a whole. Soil tillage and ridge making activities have the capability of redistributing $20-40 \mathrm{~cm}$ down layered soil to the top surface and radioactive elements initially associated with the soil also reach the top surface. The perceived implication of these activities is that farmers who visit their farms regularly and the occupants of the immediate environments where the farms are domiciled are exposed to radiation levels above normal values. The persistent and prolonged usage of the fertilizers can redistribute, restructure or elevate the level of primordial radionuclides in the soil profile 
(Khater, 2008; Ahialey et al., 2014). Also, the radioactivity levels in crops grown on fertilizer enhanced soils may also increase, through various uptake mechanisms from soil to plant.

High radiation levels and doses in the environment are detrimental to human health. Ionizing radiations are highly energetic particles with characteristic high penetrating power. When such radiation passes through the biological cell, it causes both excitation and ionization which alters the cells structure (Emelue et al., 2014). Exposure to high levels of gamma radiation causes a number of harmful effects in man such as mutation and cancer of various types (Aziz et al., 2014) and different kinds of diseases (Taskin et al., 2009). Due to the radioactive contents of fertilizers and other agro chemicals, it is demanded that farming environments as well as farmers are adequately protected against high radiation levels and doses. It is necessary that for any farming environment, baseline data about radiation levels be provided. These will provide bases for assessing and monitoring any additions following any farming activity. It will also serve as a guide in any epidemiological study of diseases traceable to radiation. The perceived implication of increase background radiation levels of farmlands due to inputs of fertilizers and other agrochemicals suggest the need to investigate the background ionization radiation levels and doses in selected farms located in communities of Ishielu LGA of Ebonyi State. This pioneering study in the area is aimed at providing baseline data of background radiation in the farming environments. The study will provide bases for assessing and monitoring any additions to the radiation levels of the environment in future farming seasons.

\section{MATERIALS AND METHODS}

Study area: Ishielu is a local government area (LGA) in Ebonyi State, Nigeria with administrative headquarters in the town of Ezillo. The study was carried out in four communities of the LGA which are Nkalagu, Ezillo, Okpoto and Nteze. The major occupation of the people is farming and trading. Five farmlands from each community were selected for background radiation level measurement. Figure 1 shows the map of Ebonyi State showing the study LGA.

Sampling and Measurement: Measurement of terrestrial outdoor background ionizing radiation (BIR) levels in the selected farms was done using a portable GQ GMC-320 Plus nuclear radiation detector meter (manufactured by GQ Electronics LLC, USA). The detector contains a Geiger Muller tube capable of detecting $\alpha, \beta, \gamma$ and $\mathrm{x}$-rays. When radiation passes through the Geiger tube, it triggers an electrical pulse which the CPU registers as a count and it is displayed on the screen in units of CPM, mR/h or $\mu \mathrm{Sv} / \mathrm{h}$.

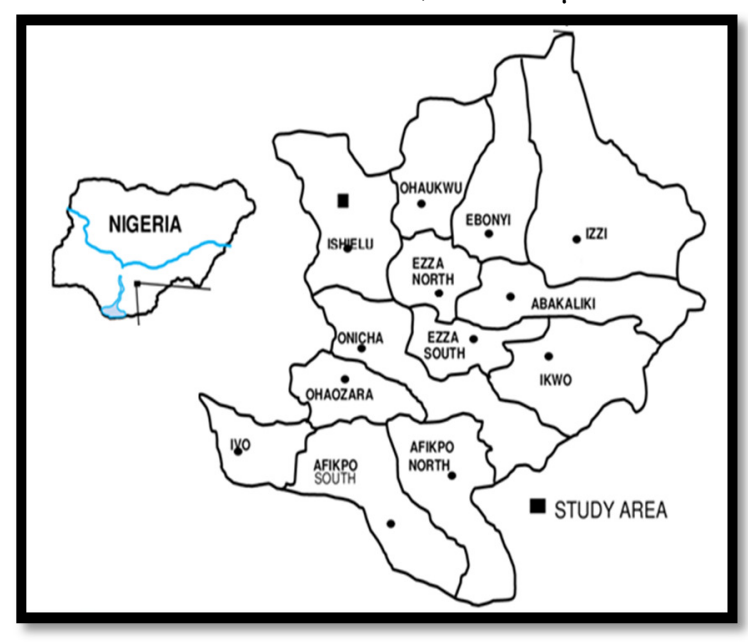

Fig 1: Map of Ebonyi State showing the study area

The study was conducted in two months; April and May, 2018. Five farms were selected from each community and the precise locations of the farms were determined using a geographical positioning system (GPS). For each month, three BIR measurements were taken for each farm at an interval of four minutes to account for any error due to fluctuation in the environment parameters (Agbalagba, 2017). These were then averaged to a single BIR exposure reading denoted as first and second BIR levels for the two months respectively.

The mean value of the two average BIR readings for the two months were determined and denoted as mean BIR exposure rates for each farm. Readings were taken between the hours of 1300 and 1600 because the radiation meter has a maximum response to radiation within these hours as recommended by the National Council on Radiation Protection and Measurements (NCRP, 1993). An in-situ approach of measurement with the standard practice of elevating the detector tube $1.0 \mathrm{~m}$ above ground level with its window facing the point under investigation was adopted to enable sample points maintain their original environmental characteristics (Agbalagba et al, 2016; Ugbede and Echeweozo, 2017). The mean BIR exposure rate obtained were quantitatively used to assess the radiation health impact to farmers in the immediate environments by performing a number of radiological health indices calculations such as absorbed dose rate, annual effective dose equivalent and excess lifetime cancer risk using the necessary relations given by Rafique et al (2014) and Agbalagba (2017). The radiation absorbed dose rates were evaluated using equation (1). 


$$
1 \mu R h^{-1}=8.7 \eta G y h^{-1}=\frac{8.7 \times 10^{-3}}{(1 / 8760 y)} \mu G y y^{-1}
$$

The computed absorbed dose rates were used to calculate the annual effective dose equivalent (AEDE) using equation (2).

$$
A E D E=A D R(\eta G y / h) \times 8760 h \times 0.7 S v / G y \times 0.2(2)
$$

Where ADR is the absorbed dose rate in $\eta \mathrm{Gy} / \mathrm{h}, 8760$ is the total hours in a year, $0.7 \mathrm{~Sv} / \mathrm{Gy}$ is the dose conversion factor from absorbed dose in air to the effective dose with an occupancy factor of 0.2 for outdoor exposure as recommended by UNSCEAR (2008).

The excess lifetime cancer risks were evaluated using the annual effective dose values by employing equation (3).

$$
E L C R=A E D E\left(m S v y^{-1}\right) \times D L \times R F
$$

Where AEDE is the annual effective dose equivalent, $\mathrm{DL}$ is average duration of life (70 years) and RF is the fatal cancer risk factor per sievert $\left(\mathrm{Sv}^{-1}\right)$. For low-dose background radiation, which is considered to produce stochastic effects, ICRP 103 uses a fatal cancer risk factor value of 0.05 for public exposure (ICRP, 2007).

\section{RESULTS AND DISCUSSION}

The results for the BIR exposure level measurements and the associated radiological health parameters for the Nkalagu, Ezillo, Okpoto and Nteze are given in Tables 1 and 2 respectively. As shown in Table 1, the BIR levels for Nkalagu farms range from 0.014 to $0.023 \mathrm{mR} / \mathrm{h}$ with mean value of $0.016 \pm 0.002 \mathrm{mR} / \mathrm{h}$. Those at Ezillo farms range from 0.013 to $0.020 \mathrm{mR} / \mathrm{h}$ with same mean value of $0.016 \pm 0.001 \mathrm{mR} / \mathrm{h}$. In Okpoto farms, the BIR levels range from 0.011 to $0.016 \mathrm{mR} / \mathrm{h}$ with mean value of $0.013 \pm 0.001 \mathrm{mR} / \mathrm{h}$. Similarly, the BIR levels in Nteze farms range from 0.011 to $0.018 \mathrm{mR} / \mathrm{h}$ with same mean value of $0.013 \pm 0.001 \mathrm{mR} / \mathrm{h}$. This variation in BIR values can be attributed to the different agrochemicals and fertilizers contents and their concentration in the farm soil and also to the different geological and geophysical characterization of the environments.

The raw material used in production of some fertilizers is phosphate ore containing various amounts of radioactive elements (El-Zakla et al., 2007). During phosphate ore processing, owing to chemical properties of Radium, practically all ${ }^{226} \mathrm{Ra}$ gets incorporated into phosphogypsum and remains in disequilibrium status in comparison with the radioactivity levels of the raw materials (El-Zakla et al., 2007). This has the capability of raising the radioactivity content of the soil and consequently the radiation levels of the farming environment. The mean BIR level of farmlands located at Nkalagu and Ezillo exceeded the $0.013 \mathrm{mRh}^{-1}$ recommended ambient BIR exposure level (ICRP, 2007; Osimobi et al, 2015; Agbalagba et al 2016) while those at Okpoto and Nteze are in agreement. The values also show that the BIR levels in all the farmlands studied within Nkalagu community are above the recommended safe limit and are also higher than those observed in the other communities. The high BIR levels in Nkalagu can be attributed to the limestone mineral deposit located in Nkalagu environment which has been exploited for the production of cement by the old Nigeria Cement Company (NIGERCEM) (Ikhane et al., 2009). Okpoto and Nteze farmlands recorded lower BIR levels. Similar low range BIR levels and radiation doses have also been observed by Ugbede and Echeweozo (2017) around quarry environment in Okpoto community.

The BIR values recorded in all the farmlands are higher than mean value of $0.009 \pm 0.0004 \mathrm{mR} / \mathrm{h}$ reported by Mokobia and Oyibo (2017) in farmlands located in the 25 local government areas of Delta State, Nigeria. The variation of the BIR levels of the surveyed farmlands in comparison with UNSCEAR (2008) and ICRP (2007) recommended value is depicted in Figure 2. The corresponding mean absorbed doses and annual effective dose equivalent (Table 2) as a result of BIR exposure are respectively $142.68 \pm 14.73 \mathrm{nGy} / \mathrm{h}$ and $0.145 \pm 0.07 \mathrm{mSv} / \mathrm{y}$ at Nkalagu farmlands, $140.94 \pm 11.14 \mathrm{nGy} / \mathrm{h}$ and $0.173 \pm 0.01 \mathrm{mSv} / \mathrm{y}$ at Ezillo farmlands, $113.10 \pm 7.78$ $\mathrm{nGy} / \mathrm{h}$ and $0.139 \pm 0.01 \mathrm{mSv} / \mathrm{y}$ at Okpoto farmlands and $116.58 \pm 011.21 \mathrm{nGy} / \mathrm{h}$ and $0.143 \pm 0.014 \mathrm{mSv} / \mathrm{y}$ at Nteze farmlands. The absorbed doses in all the farmlands are far higher than the world average value of $59.00 \mathrm{nGy} / \mathrm{h}$ (Monica et al, 2016; Agbalagba, 2017) and recommended safe limit of $84.0 \mathrm{nGy} / \mathrm{h}$ (UNSCEAR, 2008; Ononugbo and Mgbemere, 2016).

The annual effective dose is a radiation protection index which quantifies the whole body absorbed dose per year. The values for the annual effective dose for all the farmlands in this study are lower than the ICRP permissible limits of $1.00 \mathrm{mSv} / \mathrm{yr}$ for the general public and $20.00 \mathrm{mSv} / \mathrm{yr}$ for occupational workers within a year (ICRP, 2007). This indicates that the studied areas are in good agreement with permissible limit. The absorbed dose rates arising from the BIR levels in the farmlands and the annual effective radiation doses at these rates do not constitute any immediate radiological health effect on the farmers and the general public. 
Table 1: Background ionizing radiation levels in farmlands of Ishielu communities

\begin{tabular}{|c|c|c|c|c|c|}
\hline \multirow[t]{2}{*}{ Community } & \multirow{2}{*}{$\begin{array}{l}\text { Farmland } \\
\text { code }\end{array}$} & \multirow[b]{2}{*}{ Geographical Location } & \multicolumn{3}{|c|}{ Background ionizing radiation levels } \\
\hline & & & $\begin{array}{l}1^{\text {st }} \mathbf{B I R} \\
(\mathrm{mR} / \mathrm{h})\end{array}$ & $\begin{array}{l}2^{\text {nd }} \mathbf{B I R} \\
(\mathrm{mR} / \mathrm{h})\end{array}$ & $\begin{array}{c}\text { Mean BIR } \\
(\mathrm{mR} / \mathrm{h})\end{array}$ \\
\hline \multirow{5}{*}{ Nkalagu } & NKF1 & $\mathrm{N} 6^{\circ} 28^{\prime 2} 29.28^{\prime \prime} \mathrm{E} 7^{\circ} 46^{\prime} 22.94^{\prime \prime}$ & 0.014 & 0.016 & 0.015 \\
\hline & NKF2 & $\mathrm{N} 6^{\circ} 28^{\prime} 28.01^{\prime \prime} \mathrm{E} 7^{\circ} 46^{\prime} 16.96^{\prime \prime}$ & 0.018 & 0.014 & 0.016 \\
\hline & NKF3 & $\mathrm{N} 6^{\circ} 28^{\prime} 36.88^{\prime \prime} \mathrm{E} 7^{\circ} 46^{\prime} 19.33^{\prime \prime}$ & 0.012 & 0.016 & 0.014 \\
\hline & NKF4 & $\mathrm{N} 6^{\circ} 28^{\prime} 37.21^{\prime \prime} \mathrm{E} 7^{\circ} 46^{\prime} 14.42^{\prime \prime}$ & 0.013 & 0.015 & 0.014 \\
\hline & NKF5 & $\mathrm{N} 6^{\circ} 28^{\prime} 17.59^{\prime \prime} \mathrm{E} 7^{\circ} 46^{\prime} 57.79^{\prime \prime}$ & 0.024 & 0.021 & 0.023 \\
\hline \multirow{6}{*}{ Ezillo } & & Mean & & & $0.016 \pm 0.002$ \\
\hline & EZF1 & $\mathrm{N}^{\circ} 26^{\prime} 3.53^{\prime \prime} \mathrm{E} 7^{\circ} 48^{\prime} 43.13^{\prime \prime}$ & 0.022 & 0.018 & 0.020 \\
\hline & EZF2 & $\mathrm{N} 6^{\circ} 26^{\prime} 4.43^{\prime \prime} \mathrm{E} 7^{\circ} 48^{\prime} 37.54^{\prime \prime}$ & 0.017 & 0.015 & 0.016 \\
\hline & EZF3 & $\mathrm{N}^{\circ} 26^{\prime} 5.28^{\prime \prime} \mathrm{E} 7^{\circ} 48^{\prime} 46.54^{\prime \prime}$ & 0.016 & 0.020 & 0.018 \\
\hline & EZF4 & $\mathrm{N} 6^{\circ} 25^{\prime} 34.33^{\prime \prime} 7^{\circ} 49^{\prime} 12.78^{\prime \prime}$ & 0.011 & 0.014 & 0.013 \\
\hline & EZF5 & $\mathrm{N} 6^{\circ} 25^{\prime} 28.05^{\prime \prime} 7^{\circ} 49^{\prime} 18.91^{\prime \prime}$ & 0.016 & 0.012 & 0.014 \\
\hline \multirow{6}{*}{ Okpoto } & & Mean & & & $0.016 \pm 0.001$ \\
\hline & OKF1 & $\mathrm{N}^{\circ} 24^{\prime} 42.68^{\prime \prime} 7^{\circ} 51^{\prime} 48.42^{\prime \prime}$ & 0.011 & 0.013 & 0.012 \\
\hline & OKF2 & $\mathrm{N} 6^{\circ} 24^{\prime} 35.96^{\prime \prime} 7^{\circ} 51^{\prime} 46.29^{\prime \prime}$ & 0.012 & 0.010 & 0.011 \\
\hline & OKF3 & $\mathrm{N} 6^{\circ} 24^{\prime} 53.45^{\prime \prime} \mathrm{E} 7^{\circ} 52^{\prime} 25.91^{\prime \prime}$ & 0.014 & 0.010 & 0.012 \\
\hline & OKF4 & $\mathrm{N} 6^{\circ} 24^{\prime} 46.94^{\prime \prime} 7^{\circ} 52^{\prime} 13.16^{\prime \prime}$ & 0.012 & 0.016 & 0.014 \\
\hline & OKF5 & $\mathrm{N} 6^{\circ} 24^{\prime} 51.21^{\prime \prime} 7^{\circ} 51^{\prime} 37.40^{\prime \prime}$ & 0.014 & 0.017 & 0.016 \\
\hline \multirow{7}{*}{ Nteze } & & Mean & & & $0.013 \pm 0.001$ \\
\hline & NTF1 & $\mathrm{N}^{\circ} 24^{\prime} 2.50^{\prime \prime} \mathrm{E} 7^{\circ} 55^{\prime} 1.48^{\prime \prime}$ & 0.016 & 0.012 & 0.014 \\
\hline & NTF2 & $\mathrm{N6}^{\circ} 23^{\prime} 57.85^{\prime \prime} \mathrm{E}^{\circ} 55^{\prime} 6.96^{\prime \prime}$ & 0.012 & 0.010 & 0.011 \\
\hline & NTF3 & $\mathrm{N}^{\circ} 23^{\prime} 54.23^{\prime \prime} 7^{\circ} 55^{\prime} 8.91^{\prime \prime}$ & 0.014 & 0.011 & 0.013 \\
\hline & NTF4 & $\mathrm{N} 6^{\circ} 23^{\prime} 55.90^{\prime \prime} \mathrm{E} 7^{\circ} 55^{\prime} 12.53^{\prime \prime}$ & 0.010 & 0.012 & 0.011 \\
\hline & NTF5 & N6²3'50.10"E7º55'9.94" & 0.016 & 0.019 & 0.018 \\
\hline & & Mean & & & $0.013 \pm 0.001$ \\
\hline
\end{tabular}

Table 2: Radiation health indices associated with BIR in farm lands of Ishielu communities

\begin{tabular}{|c|c|c|c|c|c|}
\hline \multirow[t]{2}{*}{ Community } & \multirow{2}{*}{$\begin{array}{l}\text { Farmland } \\
\text { code }\end{array}$} & \multirow{2}{*}{ Geographical Location } & \multicolumn{3}{|c|}{ Radiation health indices } \\
\hline & & & $\begin{array}{l}\text { Absorbed dose } \\
(\eta G y / h)\end{array}$ & $\begin{array}{l}\text { Annual effective dose } \\
\text { equivalent }(\mathrm{mSv} / \mathrm{y})\end{array}$ & $\begin{array}{c}\text { Excess lifetime } \\
\text { cancer risk } \times 10^{-3}\end{array}$ \\
\hline \multirow{5}{*}{ Nkalagu } & NKF1 & $\mathrm{N} 6^{\circ} 28^{\prime 2} 29.28^{\prime \prime} \mathrm{E} 7^{\circ} 46^{\prime} 22.94^{\prime \prime}$ & 130.50 & 0.160 & 0.560 \\
\hline & NKF2 & $\mathrm{N} 6^{\circ} 28^{\prime} 28.01^{\prime \prime} \mathrm{E} 7^{\circ} 46^{\prime} 16.96^{\prime \prime}$ & 139.20 & 0.171 & 0.599 \\
\hline & NKF3 & $\mathrm{N} 6^{\circ} 28^{\prime} 36.88^{\prime \prime} \mathrm{E}^{\circ} 46^{\prime} 19.33^{\prime \prime}$ & 121.80 & 0.149 & 0.522 \\
\hline & NKF4 & $\mathrm{N} 6^{\circ} 28^{\prime} 37.21^{\prime \prime} \mathrm{E} 7^{\circ} 46^{\prime} 14.42^{\prime \prime}$ & 121.80 & 0.149 & 0.522 \\
\hline & NKF5 & $\mathrm{N} 6^{\circ} 28^{\prime} 17.59^{\prime \prime} \mathrm{E} 7^{\circ} 46^{\prime} 57.79^{\prime \prime}$ & 200.10 & 0.245 & 0.858 \\
\hline \multirow{6}{*}{ Ezillo } & & Mean & $142.68 \pm 14.73$ & $0.145 \pm 0.07$ & $0.612 \pm 0.06$ \\
\hline & EZF1 & $\mathrm{N}^{\circ} 26^{\prime} 3.53^{\prime \prime} \mathrm{E} 7^{\circ} 48^{\prime} 43.13^{\prime \prime}$ & 174.00 & 0.213 & 0.746 \\
\hline & EZF2 & $\mathrm{N} 6^{\circ} 26^{\prime} 4.43^{\prime \prime} \mathrm{E} 7^{\circ} 48^{\prime} 37.54^{\prime \prime}$ & 139.20 & 0.171 & 0.599 \\
\hline & EZF3 & $\mathrm{N} 6^{\circ} 26^{\prime} 5.28^{\prime \prime} \mathrm{E} 7^{\circ} 48^{\prime} 46.54^{\prime \prime}$ & 156.60 & 0.192 & 0.672 \\
\hline & EZF4 & $\mathrm{N} 6^{\circ} 25^{\prime} 34.33^{\prime \prime E} 7^{\circ} 49^{\prime} 12.78^{\prime \prime}$ & 113.10 & 0.139 & 0.487 \\
\hline & EZF5 & $\mathrm{N} 6^{\circ} 25^{\prime 2} 28.05^{\prime \prime} \mathrm{E} 7^{\circ} 49^{\prime} 18.91^{\prime \prime}$ & 121.80 & 0.149 & 0.522 \\
\hline \multirow{6}{*}{ Okpoto } & & Mean & $140.94 \pm 11.14$ & $0.173 \pm 0.01$ & $0.605 \pm 0.05$ \\
\hline & OKF1 & $\mathrm{N} 6^{\circ} 24^{\prime} 42.68^{\prime \prime} \mathrm{E}^{\circ} 51^{\prime} 48.42^{\prime \prime}$ & 104.4 & 0.128 & 0.448 \\
\hline & OKF2 & $\mathrm{N} 6{ }^{\circ} 24^{\prime} 35.96^{\prime \prime} 7^{\circ} 51^{\prime} 46.29^{\prime \prime}$ & 95.70 & 0.117 & 0.410 \\
\hline & OKF3 & $\mathrm{N} 6^{\circ} 24^{\prime} 53.45^{\prime \prime} \mathrm{E} 7^{\circ} 52^{\prime} 25.91^{\prime \prime}$ & 104.40 & 0.128 & 0.448 \\
\hline & OKF4 & $\mathrm{N} 6^{\circ} 24^{\prime} 46.94^{\prime \prime} \mathrm{E}^{\circ} 52^{\prime} 13.16^{\prime \prime}$ & 121.80 & 0.149 & 0.522 \\
\hline & OKF5 & $\mathrm{N} 6^{\circ} 24^{\prime} 51.21^{\prime \prime E} 7^{\circ} 51^{\prime} 37.40^{\prime \prime}$ & 139.20 & 0.171 & 0.599 \\
\hline \multirow{7}{*}{ Nteze } & & Mean & $113.10 \pm 7.78$ & $0.139 \pm 0.01$ & $0.485 \pm 0.034$ \\
\hline & NTF1 & $\mathrm{N} 6^{\circ} 24^{\prime} 2.50^{\prime \prime} \mathrm{E} 7^{\circ} 55^{\prime} 1.48^{\prime \prime}$ & 121.80 & 0.149 & 0.522 \\
\hline & NTF2 & $\mathrm{N}^{\circ} 23^{\prime} 57.85^{\prime \prime} \mathrm{E}^{\circ} 55^{\prime} 6.96^{\prime \prime}$ & 95.70 & 0.117 & 0.410 \\
\hline & NTF3 & $\mathrm{N} 6{ }^{\circ} 23^{\prime} 54.23^{\prime \prime} 7^{\circ} 55^{\prime} 8.91^{\prime \prime}$ & 113.10 & 0.139 & 0.487 \\
\hline & NTF4 & $\mathrm{N} 6^{\circ} 23^{\prime} 55.90^{\prime \prime} \mathrm{E} 7^{\circ} 55^{\prime} 12.53^{\prime \prime}$ & 95.70 & 0.117 & 0.410 \\
\hline & NTF5 & $\mathrm{N} 6^{\circ} 23^{\prime} 50.10^{\prime \prime} \mathrm{E}^{\circ} 55^{\prime} 9.94^{\prime \prime}$ & 156.60 & 0.192 & 0.672 \\
\hline & & Mean & $116.58 \pm 11.21$ & $0.143 \pm 0.014$ & $0.500 \pm 0.048$ \\
\hline
\end{tabular}

However, the high BIR levels and doses at Nkalagu farmlands suggest the need for regular monitoring and regulatory actions by relevant radiation protection bodies and government agencies concerned with public health. The mean values of the excess lifetime cancer risk for the farmlands at Nkalagu, Ezillo,
Okpoto and Nteze are $0.612 \pm 0.06,0.605 \pm 0.05$, $0.485 \pm 0.034$ and $0.500 \pm 0.048$ respectively. Excess lifetime cancer risk is used to define the probability that an individual will develop cancer over his lifetime of exposure to radiation (Ugbede and Echeweozo, 2017). The values for the cancer risks obtained in this 
present study are higher when compared with world average value of $0.29 \times 10^{-3}$ (UNSCEAR, 2008; Avwiri et al, 2016). The implication of this is that farmers and members of the communities who visit the farmlands regularly and spend long hours of time are likely to develop cancer at ages of 65 to 70 years or above of their lifetime. It is very imperative that the radiation levels in these farming environments and hence the communities be monitored against any further increase.

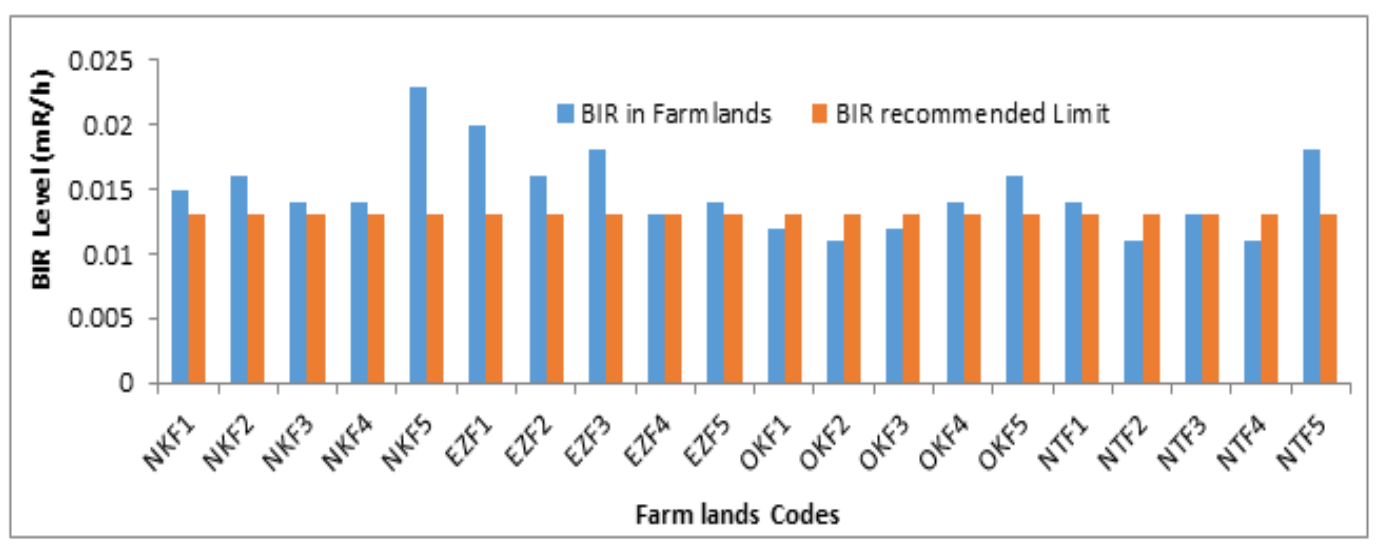

Fig 2: Comparison of BIRs in farmlands with recommended limit

Conclusion: The aim of this study was to determine the background radiation levels of farmlands in communities of Ishielu LGA of Ebonyi State. The study has thus revealed that the radiation levels in some of the farm lands are low ranging while others are high ranging which has been attributed to the geological and geographical settings of the areas as well as the fertilizers and agrochemical inputs. The related radiation doses and lifetime cancer risk values are higher than normal background value. This suggests the need for regulatory actions against any further increase in the BIR levels of the farming environment and the communities in general.

\section{REFERENCES}

Agbalagba, EO; Avwiri, GO; Ononugbo, CP (2016). GIS mapping of impact of industrial activities on the terrestrial background ionizing radiation levels of Ughelli metropolis and its environs, Nigeria. Environ. Earth Sci. 75:1425 DOI 10.1007/s12665016-6216-y

Agbalagba, OE (2017) Assessment of excess lifetime cancer risk from gamma radiation levels in Effurun and Warri City of Delta State, Nigeria. J. Taibah Univ. Sci. 11(3):367-380

Ahialey, EK; Kaka, EA; Denutsui, D; Yankey, RK; Quarshie, E; Sarfo, DK; Adotey, DK; Enti-Brown, S(2014). Evaluation of metal composition of phosphate fertilizers in Ghana. Glo. Adv. Res. J. Agric. Sci. 3(6):152-157.
Avwiri, GO; Nwaka, BU; Ononugbo, CP (2016). Radiological health risk due to gamma dose rates around Okposi Okwu and Uburu salt lakes, Ebonyi State. International J. Emerg. Res. in Manage. Technol. 5(9):36-46.

Aziz, AQ; Shahina, T; Kamal, UD; Shahid, M; Chiara, C; Abdul, W (2014). Evaluation of excessive lifetime cancer risk due to natural radioactivity in the rivers sediments of Northern Pakistan. J. Radiat. Res. Appl. Sci., 7:438-447.

Benson, ID; Ugbede, FO (2018). Measurement of background ionizing radiation and evaluation of lifetime cancer risk in highly populated motor parks in Enugu City, Nigeria. IOSR J. Appl. Phys. 10(3):77-82.

El-Zakla, T; Abdel-Ghany, HA; Hassan, AM (2007). Natural radioactivity of some local fertilizers. Romanian J. Phys. 52(5-7):731-739.

Emelue, HU; Jibiri, NN; Eke, BC (2014). Excess lifetime cancer risk due to gamma radiation in and around Warri refining and petrochemical company in Niger Delta, Nigeria, Br. J. Med. Med. Res. 4(13):2590-2598.

Farai, IP; Jibiri, NN (2000). Baseline studies of terrestrial outdoor gamma dose rate levels in Nigeria. Radiat. Prot. Dosimetry. 88(2):247-575.

ICRP. (2007). The 2007 Recommendations of the International Commission on Radiological 
Protection: Annals of the ICRP Publication 103 (pp.2-4). Elsevier.

Ikhane, PR; Folorunso, AF; Nton, ME; Oluwalaanu, JA (2009). Evaluations of Turonian limestone formation exposed at NIGERCEM-Quarry, Nkalagu, South-eastern Nigeria: A geochemical approach. The Pacific J. Sci. Technol. 10(2):763771.

Khater, AEM (2008). Uranium and heavy metals in phosphate fertilizers. Proceedings of the 5th International Conference on Uranium Mining and Hydrogeology, Freigburg-Germany.

Monica, S; Visnu Prasad, AK; Soniya, SR; Jojo, PJ (2016). Estimation of indoor and outdoor effective doses and lifetime cancer risk from gamma dose rates along the coastal regions of Kollam district, Kerala. Radiat. Prot. Environ. 39(1):38-43.

Mokobia, CE; Oyibo, B (2017). Determination of background ionization radiation (BIR) levels in some selected farms in Delta State, Nigeria. Nig. J. Sci. Environ. 15(1):27-31.

National Council on Radiation Protection and Measurements (1993). Limitation of exposure to ionizing radiation, NCRP report No.116.

Ononugbo, CP; Mgbemere, CJ (2016). Dose rate and annual effective dose assessment of terrestrial gamma radiation in Notre fertilizer plant, Onne, Rivers State, Nigeria. International J. Emerg. Res. Manage. Technol. 5(9):30-35.
Osimobi, JC; Agbalagba, EO; Avwiri, GO; Ononugbo, CP (2015). GIS mapping and background ionizing radiation (BIR) assessment of solid mineral mining sites in Enugu State, Nigeria. Open Acc. Lib. J. 2:1-9.

Rafique, M; Saeed, UR; Muhammad, B; Wajid, A; Iftikhar, A; Khursheed, AL; Khalil, AM (2014). Evaluation of excess life time cancer risk from gamma dose rates in Jhelum valley. J. Radiat. Res. Appl. Sci. 7:29-35.

Sharma, S; Kumar, A; Mehra, R (2017). Variation of ambient gamma dose rate and indoor radon/thoron concentration in different villages of Udhampur district, Jammu and Kashmir State, India. Radiat. Prot. Environ. 40(3\&4):133-141.

Taskin, H; Karavus, M; Ay, P; Topuzoglu, A; Hindiroglu, S; Karahan, G (2009). Radionuclide concentrations in soil and lifetime cancer risk due to the gamma radioactivity in Kirklareli. Turkey $J$. Environ. Radioact. 100:49-53.

Ugbede, FO; Echeweozo, EO (2017). Estimation of annual effective dose and excess lifetime cancer risk from background ionizing radiation levels within and around quarry site in Okpoto-Ezillo, Ebonyi State, Nigeria. J. Environ. Earth Sci. 7(12):74-79.

UNSCEAR (2008). United Nations Scientific Committee on the effect of Atomic Radiation. 2008 report on the sources and effects of ionizing radiation. Report to the General Assembly with scientific annexes. United Nations, New York. 